\title{
Effects of Moringa oleifera and Brosimum alicastrum partial feed substitution in intramuscular fat and adipose tissues and on the expression of lipogenic genes of Mexican hairless pigs
}

\author{
Dany A. Dzib Cauicha, Ángel C. Sierra Vásquez ${ }^{\mathrm{a}}$, Clemente Lemus Flores ${ }^{b^{*}}$, Job O. Bugarín Prado \\ Fernando Grageola Núñez ${ }^{b}$, José C. Segura Correa ${ }^{c}$, Víctor M. Moo Huchin ${ }^{d}$
}

\begin{abstract}
The present study evaluated the effects of the inclusion of ground Moringa oleifera and Brosimum alicastrum leaf meal in the diet of Mexican hairless pigs (MHP) on the amount of intramuscular fat, subcutaneous fat, leg muscle (Biceps femoris) fat, loin muscle (Longissimus dorsi) fat, leg and back fat, and the expression of lipid metabolism genes. Hairless pigs are reared in the Mexican tropics and are characterised by their body and intramuscular fat accumulation. Eighteen male pigs fed for $82 \mathrm{~d}$ were randomly allotted to three experimental isoenergetic and isoproteic diets, where M. oleifera or B. alicastrum (six pigs per diet) replaced wheat bran. The diets used were a control diet, a diet with $10 \% \mathrm{M}$. oleifera leaf meal, and a diet with $10 \%$ ground B. alicastrum leaf meal. The M. oleifera diet decreased $(P<0.05)$ the fat ratio in the Longissimus dorsi muscles, back fat, rib fat, total carcass fat, and the carcass fat: meat ratio. The B. alicastrum diet only decreased fat in the Biceps femoris muscle, back fat, and rib fat. Moringa oleifera and B. alicastrum diets also promoted the overexpression of mRNA from the stearoyl-CoA desaturase (SCD), fatty acid synthase (FASN), acetyl-CoA carboxylase alpha (ACACA), sterol regulatory element-binding protein 1 (SREBP1) and acyl carrier protein $(\mathrm{ACP})$ lipogenic genes in the Biceps femoris muscle and leg fat $(P<0.001)$. In addition, lower ACACA and SREBP1 mRNA expression in the Longissimus dorsi muscle and back fat $(P<0.001)$ were related to the lower amount of fat in pigs fed $M$. oleifera and B. alicastrum. The inclusion of Moringa oleifera and Brosimum alicastrum meals $10 \%$ in the diet of the pig MHP reduces fat, this is an important finding because fat is abundant in this type of pig.

Key words: Brosimum alicastrum, gene expression, meat quality, Mexican creole pig.
\end{abstract}

\section{INTRODUCTION}

Mexican hairless pigs (MHP) have an obese phenotype because it tends to accumulate fat from an early physiological stage (Santos et al 2011). MHP are adapted to tropical rural environments in Mexico, where they have lived for more than 500 years. They are mainly fed unconventional food resources, but also consume typical forages of the region (Becerril et al 2009, Ramos-Canché et al 2020). Despite their social and economic importance in rural and backyard communities, these pigs are considered endangered (Hernández et al 2020). However, there is a growing demand for their products (Ramos-Canché et al 2020).

The body fat accumulation of MHP and the nutritional value of their meat have been previously studied (DzibCauich et al 2020). They differ from commercial pigs in terms of performance and genetic background (LemusFlores et al 2001, Lemus-Flores et al 2020). According to Becerril et al (2009) and Aboagye et al (2019), their body fat accumulation can be attributed to genetic reasons.

Received: 27.10.2020.

Accepted: 07.06.2021.

aPostgraduate, Conkal Technological Institute, Yucatan, Mexico.

${ }^{b}$ Laboratory of Nutritional Physiology and Animal Genetics, Academic Unit of Agriculture, Autonomous University of Nayarit, Nayarit, Mexico.

${ }^{\mathrm{c} C a m p u s ~ o f ~ B i o l o g i c a l ~ a n d ~ A g r i c u l t u r a l ~ S c i e n c e s, ~ A u t o n o m o u s ~ U n i v e r s i t y ~}$ of Yucatan, Yucatan, Mexico.

${ }^{\mathrm{d} N a t i o n a l ~ T e c h n o l o g y ~ o f ~ M e x i c o / I T ~ M e r i d a, ~ M e r i d a, ~ Y u c a t a n, M e x i c o . ~}$

Corresponding author: clemus@uan.edu.mx
Specifically, the expression of lipogenic genes in, for example, adipose and muscular tissues has been found to affect fat accumulation (Duran-Montgé et al 2009, Benítez et al 2016, Fernández et al 2017, Wang et al 2020). However, the fat content of the meat is also influenced by diet composition, as in other types of pigs (Duran-Montgé et al 2009, Mohan et al 2012, Benítez et al 2016, Wood and Enser 2017).

On the other hand, the increase in back and intramuscular fat is a characteristic of local pigs of Iberian origin, which is important for the elaboration of meat products of high economic value. In these pigs, fattening is generally promoted to improve the quality of fatty acids in meat. This is the reason why, these pigs are often fed with acorns or oils with oleic fatty acids (Fernández et al 2007, Benítez et al 2016). However, feeding MHP with conventional cornsoybean diets further increases back fat, and the carcass yield is not as high as other commercial pigs (Dzib-Cauich et al 2020). Therefore, different feeding approaches should be applied to commercial and local pigs to modulate the content and quality of fat (Mohan et al 2012, Albuquerque et al 2017, Aboagye et al 2019).

An alternative to commercial pig productions in rural areas is backyard or semi-intensive pig production systems. Such systems could reduce feed and production costs, while still produce good-quality meat products (Ramos-Canché et al 2020). When social, economic, and environmental challenges are considered, tree foliage and feeding patterns are clearly sustainable for animal husbandry such as pigs. Two forage sources in tropical and subtropical environments are Moringa oleifera and 
Brosimum alicastrum trees. Their use as forage for pigs has been previously studied (Moyo et al 2011, Dzib-Cauich et al 2016, Ly et al 2016, Zhang et al 2019). They are alternative protein sources in animal feeds because of the protein content of their leaves (Castro-González et al 2008, Teixeira et al 2014). In addition, they are rich sources of fatty acids, soluble fibre, and antioxidants (Moyo et al 2011). A limitation of forages in pigs feed is that high fibre content is associated with impaired nutrient utilisation and reduction of net energy values (Thacker and Haq, 2008). However, MHP can eat up to $40 \%$ M. oleifera leaf meal without effect on its productive response (Ortiz et al 2015); this could be associated with its large intestine and more active microflora. The present research was carried out to determine the effect of the inclusion of $M$. oleifera or $B$. alicastrum leaf meal in the diet of MHP on the amount of intramuscular fat, subcutaneous fat, leg muscle (Biceps femoris) fat, loin muscle (Longissimus dorsi) fat, leg and back fat, and on the expression of genes involved in lipid metabolism in tissues.

\section{MATERIAL AND METHODS}

\section{ANIMALS AND DIETS}

The present research was carried out at the Agricultural and Livestock Production and Research Unit of the "Instituto Tecnológico de Conkal" in Yucatan, Mexico $\left(21^{\circ} 05^{\prime} \mathrm{N}\right.$ and $\left.89^{\circ} 32^{\prime} \mathrm{W}\right)$. The dominant climate of the region is warm sub-humid with rain mostly in summer. The ethics, care and welfare and handling of the pigs followed the guidelines of the official Mexican standards (NOM-062-ZOO-19991, NOM-051-ZOO-1995² and NOM-033-SAG/ZOO-2014³). In addition, the experiment was carried out following the procedures related to the handling of animals approved by ITConkal in 2015. This study is also part of a report of doctoral studies.

Moringa oleifera and Brosimum alicastrum leaves were collected from a forage bank after $55 \mathrm{~d}$ of growth. The harvested material was dehydrated in a conventional oven $^{4}$ at $50{ }^{\circ} \mathrm{C}$ for $48 \mathrm{~h}$. Subsequently, it was ground to a particle size of $1.0 \mathrm{~mm}$. The meal obtained was stored

1 Norma Oficial Mexicana NOM-062-ZOO 1999. 2001. Especificaciones técnicas para la producción, cuidado y uso de los animales de laboratorio. Available at: https://www.dof.gob.mx/nota_detalle. php?codigo $=762506 \&$ fecha $=22 / 08 / 2001$. Accesed 05.01.2019

2 Norma Oficial Mexicana NOM-051-ZOO-1995. 1996. Trato humanitario en la movilización de animals. Available at: http:// publico.senasica.gob.mx/?doc=531. Accesed 05.01.2019

3 Norma Oficial Mexicana NOM-033-SAG/ZOO-2014. 2015. Métodos para dar muerte a los animales domésticos y silvestres. Available at: https://www.gob.mx/cms/uploads/attachment/file/567758/NOM033-SAGZOO-2014_260815.pdf. Accesed 05.01.2019.

4 Terlab, (Jalisco, México) in hermetic containers until reaching $750 \mathrm{~kg}$, and the chemical composition was calculated according to the standard method of the AOAC (1997). Each value was then a mean of three measures (table 1).

Eighteen castrated MHP males with an average initial live weight of $22 \pm 1.11 \mathrm{~kg}$ were evaluated. They were distributed in a completely randomised design, each pig, representing an experimental unit. They were housed in $2.1 \mathrm{~m} \mathrm{x} 1.1 \mathrm{~m}$ individual pens with slatted floor and were allowed ad libitum access to water and feed for 82 d. The animals were identified with ear tags. All pigs were slaughtered at the end of the experimental period, regardless of their weight. The animals fasted at least 16 $\mathrm{h}$ before slaughter. The animals were sacrificed at the slaughterhouse of the Autonomous University of Yucatán by exsanguination after electrical stunning.

The control diet was based on corn, soybean meal and wheat bran. The diet of M. oleifera or B. alicastrum contained corn, soybean meal, wheat bran and $10 \%$ flour M. oleifera or $10 \%$ B. alicastrum leaf meal. The diets were isoenergetic and isoproteic, where wheat bran was replaced with M. oleifera or B. alicastrum (table 2 and 3). Diets were formulated for pigs with a live weight of 22-50 $\mathrm{kg}$ according to N.R.C. (1998). Another article reported consumption and performance productive in growth.

Samples, fat measurement, and gene expression analysis

Forty-five min after slaughter, the carcasses (meat, fat, and bones without the skin, head, legs, and viscera) of each pig were weighed immediately. Back fat was measured at the height of the 10th rib (mm), and the primary pieces were weighed, separating the meat, bone, and fat to obtain the weight of the cold carcass $(\mathrm{kg})$, performance of the carcass in relation to live weight $(\mathrm{kg})$, and carcass fat: meat ratio ( $\mathrm{kg}$ fat $/ \mathrm{kg}$ meat). Rib weight $(\mathrm{kg})$ and fat $(\mathrm{kg})$ were also measured. Fifty grams of the Longissimus dorsi and Biceps femoris muscles were obtained to quantify intramuscular fat following the methodology described by the AOAC (1997) for lipids.

In addition, at the moment of slaughter, three $0.5 \mathrm{~g}$ samples of the Longissimus dorsi muscle, Biceps femoris muscle, back fat, and intramuscular fat of the leg muscles were taken for analysis of gene expression. The samples were collected in $2.0 \mathrm{~mL}$ cryotubes with a stabilising solution (DNA/RNA Shield, Zymo Research, USA), placed on ice and stored at $-20^{\circ} \mathrm{C}$. Of the collected tissues, $75 \mathrm{mg}$ were weighed and the Direct-zolTM RNA MiniPrep kit ${ }^{5}$ was used for RNA extraction according to manufacturer instructions. The concentration and purity were quantified using Nanodrop spectrophotometry ${ }^{6}$. Subsequently, cDNA synthesis was carried out with $1000 \mathrm{ng}$ of RNA from each

\footnotetext{
5 Zymo Research (California, USA)

6 Thermo Fischer Scientific (Wilmington, USA)
} 
Table 1. Chemical composition of ground Moringa oleifera and Brosimum alicastrum leaf meal (dry matter \%), each value was mean of three measures.

\begin{tabular}{lcccc}
\hline Leaf meal & Fat & Protein & Ash & Moisture \\
\hline Brosimum alicastrum & $3.60 \pm 0.17$ & $20.63 \pm 0.01$ & $1.17 \pm 0.02$ & $9.55 \pm 0.21$ \\
Moringa oleifera & $4.97 \pm 0.14$ & $23.68 \pm 0.37$ & $1.12 \pm 0.01$ & $7.97 \pm 0.09$ \\
\hline
\end{tabular}

Table 2. Ingredients and calculated composition in experimental diets (\%).

\begin{tabular}{lccc}
\hline & \multicolumn{3}{c}{ Diet } \\
\cline { 2 - 4 } Ingredients & $\mathrm{CD}$ & MOD & BAD \\
\hline Corn & 35.96 & 38.37 & 37.95 \\
Soybean meal & 11.52 & 11.28 & 11.73 \\
Wheat bran & 48.07 & 35.91 & 36.5 \\
Sunflower oil & 2 & 2 & 2 \\
Moringa oleifera leaf meal & 0 & 10 & 0 \\
Brosimum alicastrum leaf meal & 0 & 0 & 10 \\
Calcium phosphate (monocalcium) & 1.08 & 1.13 & 1.11 \\
Calcium carbonate & 0.75 & 0.72 & 0 \\
Vitamin premix & a & 0.05 & 0.05 \\
Mineral premix & 0.05 & 0.1 & 0.1 \\
Lysine & 0.1 & 0.16 & 0.28 \\
Methionine & 0.22 & 0.03 & 0.03 \\
Salt & 0 & 0.25 & 0.25 \\
\hline
\end{tabular}

$\mathrm{CD}=$ control diet $; \mathrm{MOD}=$ Moringa oleifera diet $\mathrm{BAD}=$ Brosimum alicastrum diet.

${ }^{a}$ Content in one kg: Vitamin A, 8000000 IU; Vitamin D3, 500 IU; Vitamin E, 35000 IU; K3, 1.250 g; Thiamine, 500 mg, Riboflavin, 2 g; Piridoxin, $500 \mathrm{mg}$, Niacin, $10 \mathrm{~g}$, pantoteneic acid, $5 \mathrm{~g}$, Antioxidant, $125 \mathrm{~g}$, Vitamin B12, $7.5 \mathrm{mg}$, Biotin, $25 \mathrm{mg}$; Methionine was added on MOD and BAD diets to make it similar to $\mathrm{CD}$ diet.

${ }^{\mathrm{b}}$ Content in one kg: Iron, $100 \mathrm{~g}$; Manganese, $100 \mathrm{~g}$; Zinc, $100 \mathrm{~g}$; Copper, $10 \mathrm{~g}$; Iodine, 300 mg; Selenium $200 \mathrm{mg}$; Cobalt, 100 mg.

Table 3. Calculated chemical composition of experimental diets (\% of dry matter).

\begin{tabular}{|c|c|c|c|}
\hline & \multicolumn{3}{|c|}{ Diet $^{\mathrm{a}}$} \\
\hline & $\mathrm{CD}$ & MOD & $\mathrm{BAD}$ \\
\hline Crude protein & 16.00 & 16.00 & 16.00 \\
\hline $\mathrm{ME}^{\mathrm{b}}\left(\right.$ Mcal kg${ }^{-1}$ of feed $)$ & 2.91 & 2.86 & 2.88 \\
\hline Ether extract & 5.67 & 5.62 & 5.69 \\
\hline Neutral detergent fiber & 24.71 & 22.90 & 23.63 \\
\hline Acid detergent fiber & 7.88 & 8.95 & 8.95 \\
\hline $\mathrm{Ca}$ & 0.60 & 0.60 & 0.62 \\
\hline $\mathrm{P}$ & 0.50 & 0.50 & 0.50 \\
\hline Lysine & 0.96 & 0.96 & 0.96 \\
\hline Methionine & 0.26 & 0.26 & 0.26 \\
\hline $\mathrm{Ca} / \mathrm{P}$ & 1.20 & 1.22 & 1.23 \\
\hline
\end{tabular}

${ }^{\mathrm{a}} \mathrm{CD}=$ control diet $\mathrm{MOD}=$ Moringa oleifera diet $\mathrm{BAD}=$ Brosimum alicastrum diet.

${ }^{\mathrm{b}} \mathrm{ME}=$ metabolizable energy. 
Table 4. Sequence of primers used for gene expression analysis.

\begin{tabular}{|c|c|c|c|c|}
\hline Genes & Primer sequence $5^{\prime} \rightarrow 3^{\prime}$ & $\begin{array}{l}\text { Amplicon length } \\
\text { (bp) }\end{array}$ & $\operatorname{Tm}{ }^{\circ} \mathrm{C}$ & Access number \\
\hline ACACA & $\begin{array}{l}\text { F- ATGTTTCGGCAGTCCCTGAT } \\
\text { R- TGTGGACCAGCTGACCTTGA }\end{array}$ & 133 & 62 & AF175308 \\
\hline FASN & $\begin{array}{l}\text { F- CGTGGGCTACAGCATGATAG } \\
\text { R- GAGGAGCAGGCCGTGTCTAT }\end{array}$ & 108 & 64 & AY954688 \\
\hline $\mathrm{ACP}$ & $\begin{array}{l}\text { F-CAGCAGGCCAGGTCAGCATT } \\
\text { R- GTCGACATGCCAACGCAGGA }\end{array}$ & 236 & 60 & XM_001924222 \\
\hline SCD & $\begin{array}{l}\text { F- GCCGAGAAGCTGGTGATGTT } \\
\text { R-CAGCAATACCAGGGCACGAT }\end{array}$ & 95 & 56 & AY487829 \\
\hline SREBP1 & $\begin{array}{l}\text { F- CGGACGGCTCACAATGC } \\
\text { R-GACGGCGGATTTATTCAGCTT }\end{array}$ & 114 & 64 & NM_214157 \\
\hline RNA S18 & $\begin{array}{l}\text { F-GGCCTCACTAAACCATCCAA } \\
\text { R-TAGAGGGACAAGTGGCGTTC }\end{array}$ & 98 & 64 & XM_012100710 \\
\hline
\end{tabular}

$\mathrm{SCD}=$ stearoyl-CoA desaturase; FASN = fatty acid synthase; ACACA = acetyl-CoA carboxylase alpha; SREBP1 = sterol regulatory element-binding protein $1 ; \mathrm{ACP}=$ acyl carrier protein $; \mathrm{F}=$ forward primer; $\mathrm{R}=$ reverse primer; $\mathrm{bp}=$ base pair; $\mathrm{Tm}{ }^{\circ} \mathrm{C}=$ melting temperature; $\mathrm{RNA} \mathrm{S} 18=$ endogenous gene.

sample using the Maxima H Minus First Strand cDNA Synthesis Kit and dsDNase kit ${ }^{7}$.

Real-time polymerase chain reaction (PCR) was performed with a Step-One Plus Real-Time PCR kit ${ }^{8}$ and the SYBR Green/ROX qPCR Master Mix (2x) kit ${ }^{9}$, with a final volume of $20 \mathrm{uL}$ per reaction. The expression of the genes acetyl-CoA carboxylase alpha (ACACA), stearoylCoA desaturase ( $\mathrm{SCD}$ ), sterol regulatory element-binding protein 1 (SREBP1), acyl carrier protein (ACP), and fatty acid synthase (FASN) were evaluated (table 4). These genes have been associated with lipid metabolism in pigs (DuranMontgé et al 2009). The endogenous RNA18S gene was used to normalise gene expression. The triplicate real-time amplification of each sample was carried out in 40 cycles under the following conditions: initial denaturation at 95 ${ }^{\circ} \mathrm{C}$ for $8 \mathrm{~min}$ and cycling at $95{ }^{\circ} \mathrm{C}$ for $15 \mathrm{~s}$ and $60{ }^{\circ} \mathrm{C}$ for $30 \mathrm{~s}$. The specificity of the amplification of each array was confirmed by the dissociation curve analysis and the temperature ramp of this analysis was $60^{\circ} \mathrm{C}$ to $95^{\circ} \mathrm{C}$ over $5 \mathrm{~s}$. The reading of the dissociation curve yielded only one peak for each sample, confirming the amplification of each gene. No amplification was detected for the negative samples used as quality controls.

\footnotetext{
7 Thermo Fischer Scientific (Wilmington, USA)

8 Applied Biosystems (Stockholm, Sweden)

9 Fermentas Thermo Fischer Scientific (Wilmington, USA)
}

\section{STATISTICAL ANALYSIS}

The carcass and fat content variables were analysed using the model: $\mathrm{y}_{\mathrm{ij}}=\mathrm{D}_{\mathrm{i}}+\mathrm{e}_{\mathrm{ij}}$. where $\mathrm{D}_{\mathrm{i}}$ is the $\mathrm{i}^{\text {th }} \operatorname{diet}$ (control $\operatorname{diet}[\mathrm{CD}]$, M. oleifera $\operatorname{diet}[\mathrm{MOD}]$, and B. alicastrum diet $[\mathrm{BAD}])$. Mean differences were tested using the Duncan test $(P<0.05)$. Principal component analysis was carried out to associate the measured fat variables with the diets.

A statistical analysis of the gene expression data of each tissue was performed following the method of Steibel et al (2009) and Benítez et al (2016), which consists of the analysis of the cycle threshold value $(\mathrm{Ct})$ of the target and endogenous genes. In addition, a linear mixed model with univariate analysis of the gene expression registered for the SCD, FASN, ACACA, SREBP1, and ACP genes was used: $\mathrm{y}_{\mathrm{gijk}}=\mathrm{G}_{\mathrm{i}}+\mathrm{A}_{\mathrm{j}}+\mathrm{e}_{\mathrm{ijk}}$, where $\mathrm{y}_{\mathrm{gijk}}=-\log 2\left(\mathrm{E}_{\mathrm{g}}-\mathrm{Ct}_{\mathrm{gijk}}\right)$, $\mathrm{E}_{\mathrm{g}}$ is the PCR efficiency (E) of each gene $(\mathrm{g}), \mathrm{Ct}_{\text {gijk }}$ is the value obtained from the thermal cycler software for the gene corresponding to the $\mathrm{k}^{\text {th }}$ repetition of the $\mathrm{j}^{\text {th }}$ animal belonging to the $\mathrm{i}^{\text {th }}$ group, $\mathrm{G}_{\mathrm{i}}$ is the $\mathrm{i}^{\text {th }}$ group-specific effect on gene expression, $\mathrm{A}_{\mathrm{j}}$ is the specific random effect on the quantitative polymerase chain reaction (qPCR) expression of the gene in the $\mathrm{j}^{\text {th }}$ pig, and $\mathrm{e}_{\mathrm{ijk}}$ is the residual effect. Three different groups corresponding with the CD, MOD, and BOD diets were considered in the model. Differences were obtained between groups in the expression rate of the genes of interest (diffG $=$ control group-test group) normalised by the endogenous gene. Contrasts were performed to obtain differences between groups for each gene (Steibel et al 2009). The adjusted $P$-values of the diffG were calculated using the Bonferroni correction method. The relative change values in gene expression (FC) were 
calculated from the estimated diffG values according to the following equation: $\mathrm{FC}=2^{\text {-diffG }}$. All calculations were performed in SPSS v. 20 (2011).

\section{RESULTS}

\section{INTRAMUSCULAR AND SUBCUTANEOUS FAT}

Carcass weight and performance were not affected by the experimental diets. The MOD diet decreased the ratio of intramuscular fat of the Longissimus dorsi muscle (IMFLD) and Biceps femoris muscle (IMFBF), back fat at the 10th rib, total carcass fat, carcass fat: meat ratio, and rib fat (table 5). The MOD and BAD diets had a similar decreasing effect on IMFBF, back fat, and rib fat compared to the control diet. The multivariate analysis of the main components shows the association of higher amounts of fat with the control diet (figure 1).

\section{GENE EXPRESSION IN LONGISSIMUS DORSI AND BICEPS FEMORIS MUSCLES, INTRAMUSCULAR FAT OF LEG MUSCLES, AND BACK FAT}

As shown in table 6, the FC of gene expression shows statistical differences between different tissue samples. In general, in the Biceps femoris muscle and the internal

Table 5. Differences mean in intramuscular and body fat of pigs fed Moringa oleifera and Brosimum alicastrum.

\begin{tabular}{|c|c|c|c|c|c|}
\hline \multirow{2}{*}{ Variable } & \multicolumn{3}{|c|}{ Diet } & \multirow{2}{*}{ SEM } & \multirow{2}{*}{$\mathrm{P}<$} \\
\hline & $\mathrm{CD}$ & MOD & BAD & & \\
\hline Slaughter weight, kg & $51.18^{\mathrm{a}}$ & $51.80^{\mathrm{a}}$ & $51.04^{\mathrm{a}}$ & 0.63 & Ns \\
\hline IMFLD, \% & $13.45^{\mathrm{a}}$ & $11.02^{\mathrm{b}}$ & $11.92^{\mathrm{ab}}$ & 0.70 & 0.05 \\
\hline $\mathrm{IMFBF}, \%$ & $10.10^{\mathrm{a}}$ & $7.57^{\mathrm{b}}$ & $8.24^{\mathrm{b}}$ & 0.64 & 0.05 \\
\hline Back fat at 10th rib, mm & $2.90^{\mathrm{a}}$ & $2.28^{\mathrm{b}}$ & $2.43^{\mathrm{b}}$ & 0.18 & 0.01 \\
\hline Cold carcass weight, $\mathrm{kg}$ & $32.97^{\mathrm{a}}$ & $34.08^{\mathrm{a}}$ & $33.21^{\mathrm{a}}$ & 0.58 & Ns \\
\hline Carcass yield, $\%$ & $64.4^{\mathrm{a}}$ & $65.79^{\mathrm{a}}$ & $65.07^{\mathrm{a}}$ & 0.51 & Ns \\
\hline Carcass total fat, $\mathrm{kg}$ & $12.91^{\mathrm{a}}$ & $11.26^{\mathrm{b}}$ & $11.55^{\mathrm{ab}}$ & 0.51 & 0.09 \\
\hline Carcass fat: meat ratio, $\mathrm{kg} / \mathrm{kg}$ & $0.87^{\mathrm{a}}$ & $0.70^{\mathrm{b}}$ & $0.74^{\mathrm{ab}}$ & 0.05 & 0.05 \\
\hline Rib fat, $\%$ & $35.36^{\mathrm{a}}$ & $30.14^{\mathrm{b}}$ & $28.94^{\mathrm{b}}$ & $1 . .89$ & 0.01 \\
\hline
\end{tabular}

a,b Values with different superscripts differ within a file $(P<0.05)$.

$\mathrm{CD}=$ control diet $\mathrm{MOD}=$ Moringa oleifera diet $; \mathrm{BAD}=$ Brosimum alicastrum diet; IMFLD = intramuscular fat of the Longissimus dorsi muscle $;$ $\mathrm{IMFBF}=$ intramuscular fat of the Biceps femoris muscle.

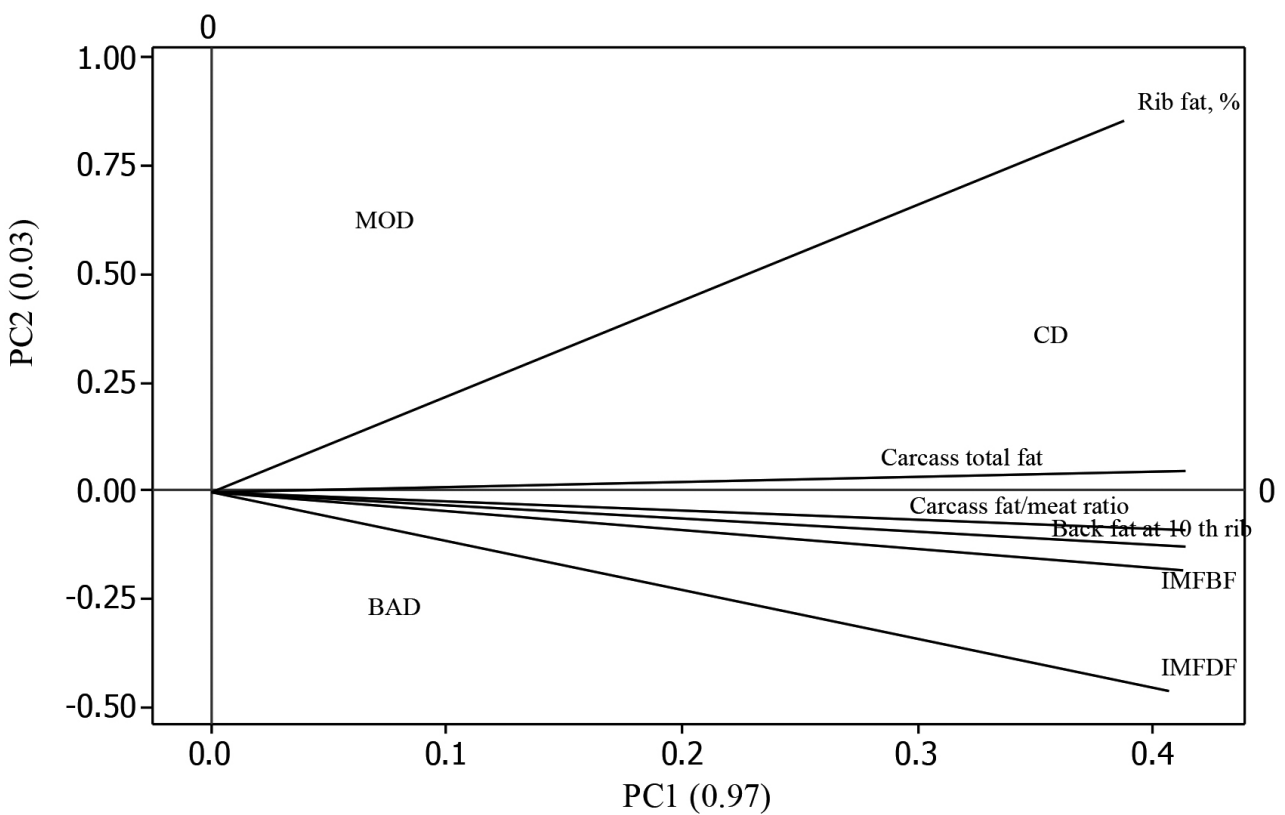

Figure 1. Principle component analysis between diets and fat measurement variables. $\mathrm{CD}=$ control diet; $\mathrm{MOD}=$ Moringa oleifera diet; $\mathrm{BAD}=$ Brosimum alicastrum diet; IMFLD = intramuscular fat of the Longissimus dorsi muscle; IMFBF = intramuscular fat of the Biceps femoris muscle. 
Table 6. Fold change $\left(\mathrm{FC}=2^{- \text {diffG }}\right)$ of gene expression in different tissues between diets.

\begin{tabular}{|c|c|c|c|c|c|}
\hline \multirow{2}{*}{ Contrast } & \multicolumn{5}{|c|}{ Genes } \\
\hline & ACACA & $\mathrm{SCD}$ & SREBP1 & $\mathrm{ACP}$ & FASN \\
\hline \multicolumn{6}{|c|}{ Biceps femoris muscle } \\
\hline MOD-CD & $1.10 * *$ & $1.25^{* *}$ & 0.91 & $1.09 * *$ & $1.08 * *$ \\
\hline BAD-CD & $1.93 * *$ & $1.12 * *$ & $1.18 *$ & $1.75^{* * *}$ & $1.97 * *$ \\
\hline SEM & 0.01 & 0.02 & 0.08 & 0.01 & 0.03 \\
\hline \multicolumn{6}{|c|}{ Internal fat of leg muscles } \\
\hline MOD-CD & $1.21 * *$ & $1.24 * *$ & $1.55^{* *}$ & $1.07 * *$ & $1.07 *$ \\
\hline BAD-CD & $1.49 * *$ & $2.10 * *$ & $1.44 * *$ & $1.69 * *$ & $1.34 * *$ \\
\hline SEM & 0.02 & 0.01 & 0.09 & 0.02 & 0.03 \\
\hline \multicolumn{6}{|c|}{ Longissimus dorsi muscle } \\
\hline MOD-CD & $0.60 * *$ & $0.79 * *$ & $0.34 * *$ & $0.75 * *$ & $0.84 * *$ \\
\hline BAD-CD & $0.87 * *$ & $1.17 * *$ & $0.51 * *$ & $0.90 * *$ & $1.10 * *$ \\
\hline SEM & 0.02 & 0.01 & 0.02 & 0.01 & 0.02 \\
\hline \multicolumn{6}{|l|}{ Back fat } \\
\hline MOD-CD & $0.58 * *$ & $0.70 * *$ & $0.42 * *$ & $0.80 * *$ & $0.74 * *$ \\
\hline BAD-CD & $0.61 * *$ & $0.67 * *$ & $0.47 * *$ & $0.79 * *$ & $0.74 * *$ \\
\hline SEM & 0.02 & 0.01 & 0.02 & 0.01 & 0.01 \\
\hline
\end{tabular}

SCD = stearoyl-CoA desaturase; FASN = fatty acid synthase; ACACA = acetyl-CoA carboxylase alpha; SREBP1 = sterol regulatory element-binding protein 1 ; ACP = acyl carrier protein.

Values with different superscripts differ within a file $*=P<0.05, * *=P<0.001$

fat of the leg muscles, it was observed that the mRNA expression of lipogenic genes was more abundant compared to the Longissimus dorsi muscle and back fat. Meanwhile, in the Biceps femoris muscle, no difference in the expression of the SREBP1 gene was observed between the MOD and CD diets. In addition, the highest expression of SCD and FASN in the Longissimus dorsi muscle was in the BAD diet followed by the MOD diet, both with respect to the CD.

\section{DISCUSSION}

These results agree with those of Mukumbo et al (2014), who found that the fat ratio of the Longissimus thoracis muscle decreased in pigs fed $7.5 \% \mathrm{M}$. oleifera leaves. Zhang et al (2019) did not observe an effect on the fat percentage of the Longissimus thoracis muscle in commercial pigs fed $3 \%$ to $9 \%$ M. oleifera for $45 \mathrm{~d}$. However, the fatty acid content was modified, with an increase in monosaturated fatty acids and omega- 3 . These results are similar to those of Dzib-Cauich et al (2016) in MHP fed $20 \%$ to $40 \%$ M. oleifera in the diet. Pérez and García (2017) in Cuba fed 20\% M. oleifera for $60 \mathrm{~d}$ and found a decrease in back fat without an effect on weight and carcass performance.

The inclusion of these forage species in animal feed is multipurpose because they have good bromatological characteristics, good palatability and digestibility, and a low amount of antinutritional compounds (Ly et al 2016,
Rojas-Schroeder et al 2017). In addition, M. oleifera and B. alicastrum forages are characterised by a large amount of bioactive compounds, including vitamins, carotenoids, and polyphenols (Moo-Huchin et al 2019). Thus, the consumption of their seeds and leaves has been shown to have beneficial effects (Moyo et al 2011, Rojas-Schroeder et al 2017). In addition, $M$. oleifera leaves reduced the levels of phospholipids, triglycerides, and cholesterol in the serum of growing pigs (Adegbenro et al 2016), suggesting a general reduction in lipid mobilisation and lipogenesis and confirming its relationship with a decrease in body fat. Adisakwattana and Chanathong (2011) evaluated M. oleifera leaf extract (in distilled water) in vitro and found that it led to a decrease in the enzymatic activity of pancreatic cholesterol esterase, which is related to lipid digestion and absorption. Specifically, the hydrolysis of cholesterol ester is catalysed by pancreatic cholesterol esterase, which releases cholesterol to the small intestine. Therefore, the inhibition of cholesterol esterase activity limits the absorption of cholesterol in the diet. Furthermore, phenolic compounds present in M. oleifera and B. alicastrum, such as phenolic acids and flavonoids (Moo-Huchin et al 2019), could contribute to the fat-reducing effects and play an important role in lipid regulation (Ezzat et al 2020). Zhang et al (2020) showed that the inclusion of $0.50 \%$ and $0.75 \%$ fermented $M$. oleifera leaves in the diet of white Peking ducks had a positive effect on the productive performance and characteristics of the carcass, reducing lipid deposition in liver and adipose tissues. This result 
was associated with a reduction in serum adiponectin levels and an increase in leptin and insulin.

As shown here and confirmed by other studies, the incorporation of M. oleifera and B. alicastrum forage to the diet is one alternative for reducing body fat that does not affect weight or carcass performance.

The expression of lipogenic genes seems to differ according to tissue and diet, which affect lipid metabolism (Duran-Montgé et al 2009, Benítez et al 2016, Fernández et al 2017, Wang et al 2020). SCD is related to fatty acid esterification and ACP, ACACA, and FASN with lipogenesis, whereas, SREBP1 is a transcription factor. In the present study, the increase in the mRNA expression of lipogenic genes in pigs fed MOD and BAD diets in Biceps femoris muscle and internal fat of leg muscles was not related to a decrease in the amount of fat, indicating possible changes in novo fatty-acid synthesis, which was not studied here. However, MHP meat is known for its nutritional value, specifically, its high proportions of polyunsaturated fatty acids, omega6 , omega-3, docosahexaenoic acid. It also contains high proportions of palmitoleic acid/palmitic acid, oleic acid/ stearic acid, linoleic acid/oleic acid, linoleic acid more linolenic acid/oleic acid, and lower values of saturated fatty acids and monounsaturated fatty acids (Dzib-Cauich et al 2020). Similar results were found in Iberian pigs (Benítez et al 2016, Fernández et al 2017). This effect could be explained through the SCD gene, which is the main enzyme involved in the synthesis of fatty acids. This enzyme is involved in the desaturation process necessary for MUFA biosynthesis, particularly for the synthesis of oleic acid from stearic and for the synthesis of palmitoleic from palmitic fatty acids (Fernández et al 2017).

Guillevic et al (2009) obtained identical results after feeding pigs sunflower or flaxseed oil. The carcass characteristics were not affected, and the lipid content of tissues did not increase, indicating that the enzymatic activity of lipid metabolism-related enzymes was poorly altered. However, they found that the fatty acid content was affected by the ingredients in the diet. In the present study, the decrease in the mRNA expression of the five lipogenic genes in the Longissimus dorsi muscle and back fat suggests an effect of the decrease in IMFLD, back fat at the 10th rib, total carcass fat, carcass fat: meat ratio and rib fat. According to Wang et al (2020), the low expression of FASN could be reflected in a lower intramuscular fat deposition because it is a predictor of the intramuscular fat content of the Longissimus dorsi muscle. The low expression of SREBP1, a transcription factor, is associated with the low expression of ACP, FASN, and SCD, as occurred in MOD (Mohan et al 2012). According to Mohan et al (2012) and Benítez et al (2018), a sunflower oil diet decreased the expression of FASN, SCD, and SREBP1. The decrease in SREBP1 could be due to an increase in the omega- 6 polyunsaturated fatty acids, which in turn would reduce the expression of FASN and SCD. DuranMontgé et al (2009) observed that the expression of the FASN and SCD genes was reduced in the liver and muscle of pigs fed with polyunsaturated fatty acids, as similarly found here for MOD.

The expression of ACACA and SREBP1 could be related to the lower amount of fat present in the pigs fed the MOD and BAD diets. ACACA plays a fundamental role in the metabolism of fatty acids and acts as an intermediary in the de novo synthesis of long-chain fatty acids (Muñoz et al 2007), and the SREBP1 gene is a regulator of the action of other genes in lipid metabolism and accumulation (Chen et al 2008, Mohan et al 2012). The over-expression of SREBP1 in MHP has been related to an increase in the intramuscular fat of the Longissimus dorsi muscle compared to commercial pigs fed a corn-soy diet (Dzib-Cauich et al 2020). Also, in the present study, the SCD and FASN genes were overexpressed in the Longissimus dorsi muscle and back fat and showed differences between the BAD and MOD diets, probably in association with the decrease in the amount of fat.

Internal fat of leg muscles, Biceps femoris muscle, loin back and Longissimus dorsi, the expressions of the genes differed as previously reported, indicating that the lipogenic action varies according to tissue and diet (Duran-Montgé et al 2008, Duran-Montgé et al 2009, Benítez et al 2016). The present study demonstrates that the M. oleifera diet decreased the ratio of intramuscular fat of the Longissimus dorsi muscle, intramuscular fat of the Biceps femoris muscle, back fat, total carcass fat, carcass fat: meat ratio, and rib fat. The B. alicastrum diet only decreased IMFBF, back fat, and rib fat compared with the control diet. In addition, the inclusion of M. oleifera and B. alicastrum leaf meal in the diet increased the mRNA expression of the lipogenic genes (SCD, FASN, ACACA, SREBP1, and ACP) in the Biceps femoris muscle and in the intramuscular fat of the leg muscles and decreased gene expression in the Longissimus dorsi muscle and back fat. The low expression of ACACA, mRNA, and SREBP1 in the Longissimus dorsi muscle and back fat was associated with the lower amount of fat in these tissues in pigs fed both the M. oleifera and B. alicastrum diets.

\section{ACKNOWLEDGEMENTS}

The authors would like to thank the Consejo Nacional de Ciencia y Tecnología (CONACYT) for the scholarship provided to the first author.

\section{REFERENCES}

Aboagye G, Zappaterra M, Pasini F, Dall'Olio S, Davoli R, et al. 2019. Fatty acid composition of the intramuscular fat in the longissimus thoracis muscle of Apulo-Calabrese and crossbreed pigs. Livest Sci 232, 103878.

Adegbenro M, Agbede JO, Onibi GE, Aletor VA. 2016. Composite leaf meal: effects on haematology and biochemical indices of growing pigs. Arch Zootech 19, 65-76. 
Adisakwattana S, Chanathong B. 2011. $\alpha$-glucosidase inhibitory activity and lipid-lowering mechanisms of Moringa oleifera leaf extract. Eur Rev Med Pharmaco Sci 15, 803-808.

Albuquerque A, Neves JA, Redondeiro M, Laranjo M, Félix MR, et al. 2017. Long term betaine supplementation regulates genes involved in lipid and cholesterol metabolism of two muscles from an obese pig breed. Meat Sci 124, 25-33.

AOAC, Association of Official Analysis Chemistry. 1997. Official Methods of Analysis. $15^{\text {th }}$ ed. Gaithersburg, MD, USA.

Benítez R, Núñez YA, Fernández B, Rodríguez C, Daza A, et al. 2016. Adipose tissue transcriptional response of lipid metabolism genes in growing Iberian pigs fed oleic acid v. carbohydrate enriched diets. Animal 10, 939-46.

Benítez R, Fernández A, Isabel B, Núñez Y, De Mercado E, et al. 2018. Modulatory effects of breed, feeding status, and diet on adipogenic, lipogenic, and lipolytic gene expression in growing Iberian and Duroc pigs. Int J Mol Sci 19, 1-20.

Castro-González A, Alayón-Gamboa JA, Ayala-Burgos A, Ramírez-Avilés L. 2008. Effects of Brosimum alicastrum and Lysiloma latisiliquum mixtures on voluntary intake, nutrient digestibility and nitrogen balance in sheep fed tropical pastures. Anim Feed Sci Tech 141, 246-258.

Chen J, Yang XJ, Xia D, Chen J, Wegner J, et al. 2008. Sterol regulatory element binding transcription factor 1 expression and genetic polymorphism significantly affect intramuscular fat deposition in the longissimus muscle of Erhualian and Sutai pigs. J Anim Sci 86, 57-63.

Duran-Montgé P, Realini CE, Barroeta AC, Lizardo R, Esteve-García E. 2008. Tissue fatty acid composition of pigs fed different fat sources. Animal 2, 1753-1762.

Duran-Montgé P, Theil PK, Lauridsen C, Esteve-García E. 2009. Fat metabolism is regulated by altered gene expression of lipogenic enzymes and regulatory factors in liver and adipose tissue but not in semimembranosus muscle of pigs during the fattening period. Animal 3, 1580-1590.

Dzib-Cauich D, Ortíz J, Sierra A, Sauri E, Palacios V. et al. 2016. Effect of Moringa oleifera meal inclusion on meat quality from the mexican hairless pig. ARPN J Agric Biol Sci 11, 131-141.

Dzib-Cauich D, Lemus-Flores C, Bugarín-Prado JO, Ayala-Valdovinos MA, Moo-Huchin VM. 2020. Perfil de ácidos grasos en músculo Longissimus dorsi y expresión de genes asociados con metabolismo lipídico en cerdos pelón mexicanos y cerdos Landrace-Yorkshire. Livest Res Rural Develop 32, 115

Ezzat SM, El Bishbishy MH, Aborehab NM, Salama MM, Hasheesh A, et al. 2020. Upregulation of MC4R and PPAR- $\alpha$ expression mediates the anti-obesity activity of Moringa oleifera Lam. in high-fat dietinduced obesity in rats. J Ethnopharmacol 251, 112541.

Fernández M, Ordóñez JA, Cambero I, Pin CC, De la Hoz L. 2007. Fatty acid compositions of selected varieties of spanish dry ham related to their nutritional implications. Food Chem 101, 107-112.

Fernández AI, Óvilo C, Barragán C, Rodríguez MC, Silió L, et al. 2017. Validating porcine SCD haplotype effects on fatty acid desaturation and fat deposition in different genetic backgrounds. Livest Sci 205, 98-105.

Guillevic M, Maryline K, Jacques M. 2009. Effect of a linseed diet or a sunflower diet on performances, fatty acid composition, lipogenic enzyme activities and stearoyl-CoA-desaturase activity in the pig. Livest Sci 124, 288-294.

Hernández AÁ, García MCA, García MAM, Ortiz OJR, Sierra VAC, et al. 2020. Sistema de producción del cerdo pelón mexicano en la Península de Yucatán. Nova Scientia 24, 1-21.

Lemus-Flores C, Ulloa-Arvizu R, Ramos-Kuri M, Estrada FJ, Alonso RA. 2001. Genetic analysis of mexican hairless pig populations. $J$ Anim Sci 79, 3021-3026.

Lemus-Flores C, Alonso-Morales R, Toledo-Alvarado H, Sansor-Nah R, Burgos-Paz W, et al. 2020. Diversidad genética y estructura poblacional del cerdo negro lampiño de Yucatán usando chip SNP50. Abanico Vet 10, 1-12.
Ly J, Samkol P, Phiny C, Bustamante D, Caro Y. 2016. Balance of nitrogen in pigs fed with Moringa oleifera foliage meal. Revista Bio Ciencias 3, 349-358.

Mohan N, Harihara I, Babul C, Madan S, Anubrata D, et al. 2012. Effect of dietary sunflower oil and coconut oil on adipose tissue gene expression, fatty acid composition and serum lipid profile of grower pigs. Arch Anim Nutr 66, 271-282.

Moo-Huchin VM, Canto-Pinto JC, Cuevas-Glory LF, Sauri-Duch E, Pérez-Pacheco E, et al. 2019. Effect of extraction solvent on the phenolic compounds content and antioxidant activity of Ramon nut (Brosimum alicastrum). Chem Pap 73, 1647-1657.

Moyo B, Masika PJ, Hugo A, Muchenje A. 2011. Nutritional characterization of moringa (Moringa oleifera Lam.) Afr J Biotechnol 10, 12925-12933.

Mukumbo FE, Maphosa A, Nkukwana TTH, Mabusela TP, Muchenje V. 2014. Effect of Moringa oleifera leaf meal on finisher pig growth performance, meat quality, shelf life and fatty acid composition of pork. S Afr J Anim Sci 44, 388-400.

Muñoz G, Alves E, Fernández A, Ovilo C, Barragán C, et al. 2007. QTL detection on porcine chromosome 12 for fatty-acid composition and association analyses of the fatty acid synthase, gastric inhibitory polypeptide and acetyl-coenzyme A carboxylase alpha genes. Anim Genet 38, 639-646.

NRC, National Research Council. 1998. Nutrient Requirements of Swine. $10^{\text {th }}$ ed. National Academy of Sciences Press, Washington, DC, USA.

Ortiz J, Palacio V, Dzib D, Sierra A, Sanguinés R, et al. 2015. Efecto del consumo de Moringa oleífera sobre el crecimiento del cerdo pelón de Yucatán. AICA 6, 452-459.

Pérez Y, García J. 2017. Efecto de la inclusión de 20\% de harina de Morera (Morus alba) o Moringa (Moringa oleífera) en la dieta sobre los rasgos de comportamiento, calidad de la canal y la carne de cerdos cebados de 40 a $85 \mathrm{~kg}$ de peso. Livest Res Rural Develop 29, 46.

Ramos-Canché ME, Magaña-Magaña MA, Aguilar-Urquizo E, PechZapata A, Piñeiro-Vázquez AT, et al. 2020. Óptimos económicos en la cría del cerdo pelón mexicano: propuesta de integración para cadena productiva. Ecosist Recur Agropec 7, e2302.

Rojas-Schroeder JA, Sarmiento-Franco L, Sandoval-Castro CA, SantosRicalde RH. 2017. Use of foliage from ramon (Brosimum Alicastrum Swarth) in animal feeding. Trop Subtrop Agroecosyst 20, 363-371.

Santos RH, Wilberth L, Walter OH. 2011. Carcass yield and thoracic and abdominal viscera growth from 25 to $45 \mathrm{~kg}$ in creole hairless pigs. Rev Científica FCV-LUZ 21, 396-402.

SPSS, IBM SPSS Statistics for Windows. 2011. Version 20.0. Armonk, IBM Corp, NY, USA.

Steibel JP, Poletto R, Coussens PM, Rosa GJM. 2009. A powerful and flexible linear mixed model framework for the analysis of relative quantification RT-PCR data. Genomics 94, 146-152.

Teixeira EMB, Carvalho MRB, Neves VA, Silva MA, Arantes-Pereira L. 2014. Chemical characteristics and fractionation of proteins from Moringa oleifera Lam. leaves. Food Chem 147, 51-54.

Thacker PA, Haq I. 2008. Nutrient digestibility, performance and carcass traits of growing-finishing pigs fed diets containing graded levels of dehydrated lucerne meal. J Sci Food Agric 88, 2019-2025.

Wang H, Jin W, Dan-dan Y, Zong-li L, Yong-qing Z, et al. 2020. Expression of lipid metabolism genes provides new insights into intramuscular fat deposition in Laiwu pigs. Asian-Australas J Anim Sci 3, 390-397.

Wood JD, Enser M. 2017. Manipulating the fatty acid composition of meat to improve nutritional value and meat quality. In: Purslow PP (ed). New aspects of Meat quality. From genes to ethics. Woodhead Publishing Limited, Duxford, UK. Pp 501-535.

Zhang T, Si B, Tu Y, Cui K, Zhou Ch, et al. 2019. Effect of including different levels of moringa (Moringa oleifera) leaf meal in the diet of finishing pigs: Performance, pork quality, fatty acid composition, and amino acid profile. Czech J Anim Sci 64, 141-149.

Zhang X, Sun Z, Cai J, Wang G, Wang J, et al. 2020. Dietary supplementation with fermented Moringa oleifera leaves inhibits the lipogenesis in the liver of meat ducks. Anim Feed Sci Tech 260, 114336. 